\title{
Evaluation Method on Geological Deposit Potential Value
}

\author{
Zhihong Zhang \& Wei Huang \\ School of Accounting, Shandong Economic University, Jinan 250014, Shandong, China
}

Ning Xu

Aluminum Corporation of China Limited, Beijing 100082, China

E-mail: jqbai@126.com

\begin{abstract}
It is related to the realization of the benefit of state-owned resources and the long retainable development of the country to evaluate the mining property rights to improve the using rate of the mineral resources. Guided by the principle of prospective return, a method for evaluating geological potential value was put forward which emphasized on the valuation of geological techniques. A coefficient was done to represent the geological potential value which was constructed by integrating the seven factors of Geology Main Factor. A case was used to illustrate the advantages brought by the proposed method. The results showed that geological deposit potential evaluation method could effectively materialize the value of geological potential. The estimated results can be a reference for mining property rights auction and has an effect to protect the right and profit of state-owned mineral resources assets.
\end{abstract}

Keywords: Valuation of the mining property rights, Geological deposit potential, Valuation of geological techniques, Principle of prospective return

\section{Introduction}

In the auction of mining property rights, the auction price sometimes is much higher than the evaluated price which leads to some questions on the objectivity, rationality, fairness and reliability of the mining property right evaluation, such as, how to reflect the real value on earth and make a reasonable price to prevent the loss of state-owned assets before the real auction? (Yu, 2006)

Mining property right evaluation in some western countries such as USA, Canada has been developed and now are organized and managed by the relevant association. The evaluating methods are becoming sufficient. Among all methods, the market method is the first choice, and the second one is the cash flow method. Besides, the joint exploration agreement method is also common because of the exists of many joint venture explorations in these western countries.

In China, the reform of mineral resources management system has been sprung up for just 10 years following above mentioned western countries. In recent years, researches on the mining theory and methods are paid attention in the mining industry. The valuation process of the mining property rights is a multi-discipline interdisciplinary. It is the integration of the accounting, financial management, investment management, geology, asset appraisal and political economics. At the same time, the intrinsic risk of mining property right evaluation makes it initiate many new problems. All of these urge more scholars to devote themselves to the hot topic. From the related references, we can find that the geology main factors row method is mostly used in the initial stage of exploration, while the cash flow evaluation method in detailed mineral exploration right assessment ( $\mathrm{Li}, 2008$ \& Zhang, 2008). In China, there are many researches about real option methods used in mining property right valuation, but it is very difficult to apply it to practice operation. Meanwhile, the method of rough estimation with geological design puts forward a benchmarking requirement for the valuation of the mining property rights. It needs further improvements because of the less adaptability caused by the complexity in the execution.

\section{Method Construction}

\subsection{Mining property value and geological deposit potential value}

The objects of mining property right evaluation include the mineral exploration right and mining right. The rights objection is the identified or potential mineral resources reserve. The rights subject is the mining property right identity. The right value is represented by usufructuary right value, which is often a part of identified or potential mineral resources exploitation value of reserves. Mining property right value can be viewed as the value of a project, that is, the investment income of the project. Then, mineral resources value is naturally 
embedded into the value of the whole project. Then the value of the mining property right includes the mineral resources value and the monopoly value of the mineral project. Finally, the price of mining property right can be expressed by the two parts----the mineral resources price and the monopoly price of mining property right.

The content of mining property right evaluation is to evaluate geological techniques and mining right, however, the valuation of geological techniques is often neglected in practice. The core task of the valuation of geological techniques is to derive the appraisal conclusion from the geological survey results. Are the existing achievements of the mineral exploration true? Is the geologic report conclusion reliable? Does the mineral deposit potential satisfy the possibility of finding new minerals? Dose it have the expanded vision potential, and if have, how much? The recoverable reserves in the technical report can not completely represent the value of mineral resources and the resource unproved is also worthy. Unfortunately, there are some difficulties in appraisal of the resource unproved because they don't enter into market. But most of the mining property right evaluation reports only quoted the process and data of the evaluation, and did not point out the geological deposit potential and did not reflect the future geological prospecting potential reasonably. The principle of prospective return in asset appraisal is the fundamental basis to guide the evaluation researchers to judge the assets value. All assets' values are rooted in their future economic benefits for their owners or the controllers. So, the valuation results could become unbelievable if the geological deposit potential value did not be reflected in the assessment of the mining property right because this violates the prospective return principle. So, the evaluation method considering geological deposit potential value is put forward.

\subsection{Valuation of geological techniques based on geological deposit potential value}

In order to evaluate the mining geological deposit potential, valuation of geological techniques can be divided into two phases, one is for the primary stage of exploration and the other is for the advanced stage of exploration. The former is the key phase to prove whether it is necessary to carry on the further evaluation work or not, that is, to make sure the mineral deposit potential, and the latter focuses on the identification of the deposit already found, then their reserves estimation and its value can be estimated.

2.2.1 Valuation of geological techniques in the primary stage of exploration-geological deposit potential valuation method

There are differences between geological deposit potential valuation and regional exploration potential evaluation. Geological deposit potential valuation belongs to the large scale assessment. The objectives mainly include blind mine or latent mine. Based on the present works, geological deposit potential valuation valuates the deposits potential value by increasing the prediction accuracy and trying to make a detailed assessment about the space of industrial ore-body, mineralization types, ore-bodies morphology, ore resource configuration, and ore quality. Currently, there are some methods applied in geological deposit potential evaluation, such as analogy method, mathematical statistics, comprehensive information method, "Delphi Method" and GIS evaluation method based on the computer technology, etc.

2.2.2 Valuation of geological techniques in the advanced stage of exploration — found deposit valuation method

The ultimate aim of mineral reserves valuation is to make sure the mineral resources reservese in mining area and the potential possibility of the new resources to be found. The objectives of valuation are mainly mining areas which has been investigated or explored in detail. Evaluation content can be roughly divided into two aspects —one is the valuation of proven reserves and the future prospect evaluation for expanded reserves.

\section{(1) Valuation of proven reserves}

The first thing to valuate the proven reserves needs to collect all the data which is necessary in the estimation of mining resources reserves, such as mining geological prospecting report, location plan, drilling data, industrial index used to estimate the reserves and other original materials, then, the judgment of reserves credibility to the mining area can be done according to the current national relevant specification.

(2) Future prospect evaluation for expanded reserves_—valuation of geological deposit potential

Through the evaluation of expanded reserves, on the one hand, we can estimate the ore resource reserves in which mineral existence in the ore-body has already been proved but not been controlled by systemically. On the other hand, deposit potential in the mining area or outside unknown area can be valuated.

The future prospect evaluation methods mainly depends on the existing exploration engineering achievements and understanding to summary the features of ore-body, occurrence regularity, and prospecting marks and so on. Eventually, deposit potential in the mining area or outside unknown area can be valuated. 


\subsection{Geological deposit potential coefficient evaluation method}

At present, all the evaluation methods for geological deposit did not evaluate the geological deposit potential. For example, in current practice, the low level reserves can not be included in the evaluation scope, the reserve can be abandoned if the proven ore-body has been explored and utilized more than 30 years. This approach actually abandoned the proven reserves artificially which reduces the potential value without considering the potential of the mining property rights project.

\subsubsection{Determination of potential coefficient}

7 categories of Geology Main Factor Method are combined to be shown in table 1.

With the geology potential coefficient applied in the income approach and cost approach, the potential value of the mining property right can be found and can be named "geological deposit potential value" or "geology potential value".

If three display marks are not obvious, while there exist a considerable number of resources reserve in the valuated mineral exploration, we can directly apply the resources reserve in the valuation model to get the geology potential value.

\subsubsection{Implementation steps}

Firstly, make the geological technical evaluation of mining property right and the qualitative assessment on the project.

Secondly, combining qualitative evaluation, calculate geology potential coefficient, resource development condition coefficient and mining market conditions coefficient separately.

Thirdly, use the traditional methods, such as the income approach or market approach, to obtain the value of mining property right. Then the process of valuation should be illustrated considering whether the valuation is in accordance with the development conditions and market conditions. Generally speaking, if these two conditions have been applied, the resources exploitation conditions coefficient and mining market conditions have no need to reconsider any longer, and we can assign 1 to both of the coefficients separately.

Fourthly, geology potential value equals to the product of the geology potential coefficient and the result already evaluated. Normally, geology potential coefficient is more than 1 , so the added value can be got by subtracting the original value from the geology potential value. Then, the value we got from the mining valuation not only includes the value on traditional sense, but also includes geology potential value. Compared with the income approach and market approach, geology potential value is estimated according to the geology potential, it includes the new added part.

\section{Case study----Evaluation of Mining area $\mathbf{Y}$}

\subsection{Introduction}

The two companies are going to be merged; a mining property right evaluation of mining area $\mathrm{Y}$ in $\mathrm{X}$ Ltd. is needed to give a reference value to price the mining property right asset. The client confirmed the valuation date on June $30^{\text {th }}, 2007$.

According to the Interim Procedures for the Exploration Right and Mining Right Evaluation and the Guideline of Mining Industry Evaluation (2006 revised edition) etc., discounted cash flow method is adopted. Usable resources reserves and production capacity on evaluation date has been worked out. After estimation, the assessment value of mining area Y's mining property right on evaluation date (June 30th, 2007) is 345.3225million RMB.

\subsection{Revaluation: Assessment of Geological Potential Value}

\subsubsection{Adjustment Coefficient}

\section{1). Mining Market Condition Coefficient}

Market conditions have been reflected in selling prices, and this coefficient will no longer be adjusted. Namely "mining market conditions coefficient" $=1$.

\section{2). Resources Exploitation Conditions Coefficient}

The original assessment report statement is very simple. After vivificating the report, the state of some elements in the ore is not ascertained. And the peer review sheet clearly stated, the existing samples' representativeness is not enough, mineral separation effect is not good. So, get the mineral quality and processing properties mark as 0.5 , the mining technology conditions mark and the infrastructure conditions mark have been reflected in 
production design, do not need to be adjusted.

\section{3). Geology Metallogenic Potential Coefficient}

The original reserves calculation stated this mining area is beneficial to mineralization, so we set the "ore-prospecting display" as 1.1 .

The review options of mineral resources evaluation from a consultant center give the suggestions which to strengthen the deep exploration for increasing the reserves. According to estimation quantity of reserves on the geological report and the range of "mineralization strength and contain scale display" listed on the new evaluation standard, the value of 2.5 is set to this index.

"Regional ore-forming geological conditions display" don't need to be changed. We can get the adjusted coefficient as follows:

"Geology metallogenic potential coefficient"="Regional ore-forming geological conditions show" $\times$ "Ore-prospecting show" $\times "$ Mineralized strength and contain scale show" $=1 \times 1.1 \times 2.5=2.75$.

"resources exploitation conditions coefficient" $=" m i n i n g$ technology show" $\times$ "Infrastructure show" $\times$ "Ore dressing or processing quality and performance show" $=1 \times 1 \times 0.5=0.5$; "Mining market conditions coefficient" $=1$.

So, adjusted coefficient $\alpha=$ "Geology metallogenic potential coefficient" $\times$ "resources exploitation conditions coefficient" $\times$ "Mining market conditions coefficient" $=2.75 \times 0.5 \times 1=1.375$.

The result was 345.3225 million RMB valuated by discount cash flow method; put it into formula then obtain the value such as:

$$
P=P_{1} \times \alpha=345.3225 \times 1.375=474.8184 \text { million } \mathrm{RMB}
$$

This value is the gross value of mining property right, including the project value 345.3225 million RMB and the potential value 129.49523 million RMB (47481.843-34532.25).

\subsection{Validating the valuation result}

In order to verify the rationality of geological potential value calculation, using the financial model in the original assessment report, and assuming investment scale, the mining way and technical indicators, market conditions and other conditions constantly, the results recalculated according to the total reserves including future reserves are as follows:

The whole life of the mining property right is 31.84 years and the value is 489.4036 million RMB.

The new results are compared with the original ones, as shown in table 2.

The results evaluated by discount cash flow are 14.5852million RMB more than the one evaluated by geological potential coefficient method. Conclusion can be derived that the reason why the latter value is less is that this method considers the impact of ore dressing. Ore dressing adds the comprehensive costs and impacts the economic earnings of whole mine. The value by geological potential coefficient method is about 130million RMB more than the original one, with $37.50 \%$ higher. If the value got from the discount cash flow method worthy more, then, we can assure that total reserves, namely the new value, is 144 million RMB more than the original one, with $41.72 \%$ higher. Half of the value has been added thanks to the potential value.

\subsection{Assessment of results}

The potential value of the mineral exploration right has important reference. Firstly, it can influence the value judgment for the cooperative enterprises. The partner must choose the cooperator which has the potential as big as possible when the other conditions are equal. Secondly, in auction, the enterprises with large potential are more attractive when the assessment value is near. The most important thing is that geological potential value of assets plays a critical role in safeguarding the national interests, if the original capital comes from nation, when mining property right need to be transferred, the auction price can be properly increased according to the market conditions. For example, taking the mean of both prices as the price lining $((47481.843+34532.25) / 2=410.0705$ million RMB). If the market situation is very favorable, a higher price can be used as the starting price. If the mining property right buyer were informed the news that the project has large potential value, the price of 475 million RMB including the potential value can becomes a rational price. In reality, the starting price is perhaps even higher than $470 \mathrm{~m}$ RMB.

\section{Conclusions}

In this paper, based on the principle of prospective return and geology main factor method, concept of geology metallogenic potential coefficient is put forward from the point of geological techniques valuation. A way was 
presented which has both the theoretic value and operation practical to determine the value of mining property rights rationally. Case study shows its rationality and validity. Especially it has the important reference function for the maintenance of national interests.

\section{References}

Adrian Manlagnit. (2006). Mine Valuation Methods of Canada, Australia and South Africa-a Comparative Summary [EB/OL], [Online] Available: http://technology.infomine.com/aricles/1/256/valuation.mining. cost/ international. mine. valuation.aspx, 2006-12-18/20090408.

Heffernan, Virginia. (2004). Mineral Property Valuation. Engineering and Mining Journal, (8).

Li Lin. (2008). Mining Right Appraisal and Sensitivity Analysis. China university of geosciences.

Yu, Jianliang. (2006). The Valuation of the Transferred State-owned Mining Property Right_based on Stakeholder Theory and Empirical Analysi. China economic press.

Zhang, Yongxing. (2008). Mineral Appraisal Theory and Method Exploration. China university of geosciences.

Table 1. Geology potential coefficient based on the Geology Main Factor Method

\begin{tabular}{|c|c|c|}
\hline Factor category & Integrated name & Note \\
\hline $\begin{array}{l}\text { I Regional geological conditions } \\
\text { II Ore-prospecting display } \\
\text { III Mineralization strength and contain } \\
\text { scale display }\end{array}$ & $\begin{array}{l}\text { Geology potential } \\
\text { coefficient }\end{array}$ & \multirow{3}{*}{$\begin{array}{l}\text { III Mineralization strength and contain } \\
\text { scale display focus on the capability of } \\
\text { future prospect expanded reserves, not } \\
\text { only on the current proven deposit } \\
\text { scale. }\end{array}$} \\
\hline $\begin{array}{l}\text { IV Mineral quality and processing } \\
\text { properties } \\
\text { V Mining technology condition } \\
\text { VII Infrastructure conditions }\end{array}$ & $\begin{array}{l}\text { Market conditions } \\
\text { coefficient of } \\
\text { resources }\end{array}$ & \\
\hline $\begin{array}{l}\text { VI Minerals and mining right market } \\
\text { conditions }\end{array}$ & $\begin{array}{c}\text { Mining market } \\
\text { conditions coefficient }\end{array}$ & \\
\hline
\end{tabular}

Table 2. The mining property right value comparison of Y ore, X mining development Co., LTD (million RMB)

\begin{tabular}{|c|c|c|c|}
\hline Method & Value & Difference & Percentage \\
\hline $\begin{array}{c}\text { original value evaluated by } \\
\text { discount cash flow(1) }\end{array}$ & 34532.25 & $\begin{array}{c}144.0811 \\
(2)-(1)\end{array}$ & $41.72 \%$ \\
\hline $\begin{array}{c}\text { new value evaluated by discount } \\
\text { cash flow(2) }\end{array}$ & 48940.36 & $\begin{array}{c}14.5852 \\
(2)-(3)\end{array}$ & $3.07 \%$ \\
\hline $\begin{array}{c}\text { value evaluated by geological } \\
\text { potential coefficient method(3) }\end{array}$ & 34532.25 & $\begin{array}{c}(3)-(1) \\
129.4959\end{array}$ & $37.5 \%$ \\
\hline
\end{tabular}

